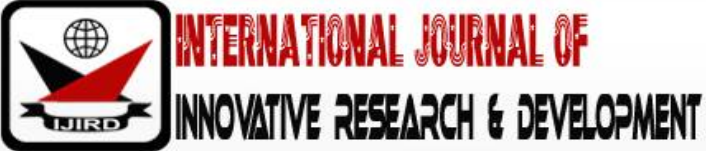

ISSN 2278-0211 (Online)

\section{Interreligious Dialogue in Indonesia's Context}

\author{
Adrianus Yohanes Mai \\ Student, Department of Theology, Mission and Ministry, \\ University of Divinity, Australia
}

\begin{abstract}
:
Interreligious dialogue is a fundamental thing in multi religions society like Indonesia. Interreligious dialogue in Indonesia's context is based on the Pancasila which is the ideology of the country. Five pillars of pancasila not merely become the starting point of interreligious dialogue but also the destiny of the dialogue. Some kinds of interreligious dialogue are pictured based on the understanding of pancasila.
\end{abstract}

Keywords: Interreligious, dialogue, Indonesia, Pancasila

\section{Introduction}

Indonesia is a home of diverse religions and various cultures. Indonesia is an archipelago country which has more than 250 million populations. It comprises over 17.000 islands and more than 300 languages. There are six official religions such as Islam 87, 01 \%, Protestant 6, 96 \%, Catholic 2, 91\%, Hindu 1, 69 \%, Buddha 0, 72 \%, Konghuchu, 0, 05\%, others $0,53 \% .{ }^{i}$ These diversities lead to the necessity of interreligious dialogue in order to foster peace and harmony. The foundation and the practice in form of interreligious dialogue in Indonesia's context will be examined in this essay in order to face its out coming and challenging. This essay will be divided into several parts: introduction, foundation of dialogue, form of dialogue, the out coming of interreligious dialogue, challenging and a conclusion.

\subsection{Pancasila as the Foundation of Interreligious Dialogue}

The foundation of interreligious dialogue in Indonesia's context is Pancasila. Literally, pancasila is a combined word in Sanskrit and Pali which means five (panca) and principles (sila). The five pillars are belief in the One God, humanity, the unity of Indonesia, democracy and social justice. Pancasila is the country's ideology or political philosophy that inspires everyone in doing anything in Indonesia including interreligious dialogue. It means that pancasila is not merely the purpose of dialogue but also the starting of interreligious dialogue.ii

According to Mukti Ali, there are two fundamental matters of interreligious dialogue in Indonesia's context: First, philosophically, the basic of interreligious dialogue is pancasila which has been becoming the philosophy of the country. It has values and principles that have been accepted by all Indonesians. Second, pragmatically, interreligious dialogue is a process of development where everyone is called to participate in it. Furthermore, interreligious has become a culture of tolerance in Indonesia which develops becoming ideology and constitutions. ${ }^{i i}$ As the ideology, pancasila leads Indonesians to put interreligious dialogue in practice in their daily lives.

\section{The Models of Interreligious Dialogue}

The practice of interreligious dialogue in Indonesia's context can be seen through four forms of interreligious dialogue in Dialogue and Proclamation such as dialogue of life, dialogue of action, dialogue of religious experience and dialogue of theological exchange.iv Based on these forms of dialogue, we will look at my personal experience in interreligious dialogue.

Dialogue of life occurs when people from different faith and spiritual tradition strive in an open neighbourhood spirit. I have been practicing this dialogue that can be found in two experiences such as visiting family and security service. I have many family members who are Islam. Therefore, it is a part of life when I visit and stay with them. I sometimes spend my holiday with my Islam families and greet them in their feast day (Ramadan). Moreover, they also visit and greet us as Christian families when we celebrate our feast day such as Christmas or Easter.

It has been a custom for many Indonesians to offer security service when other religions celebrate their feast day. Nationally, there is a large Muslim group named Banser that always offers security service during other religions celebrate their feast day. Locally, I have been involving in youth group in protecting Mosques when Muslim people celebrate their feast day. Moreover, their youth group also take part in protecting the church during Christmas or Easter.

Dialogue of action happens when people of spiritual commitment and faith collaborate with other in building a just and harmony society. I have two experiences such as service for HIV/AIDS people and involving in journalism of diversity in practising this form of dialogue. 
Personally, I joined a group named 'Caring for HIV/AIDS people' when I did my philosophy studies. This group was formed to assist those who are infected by HIV/AIDS. The members of this group are from different religions background. Moreover, those to whom this group assists are also from different religions background.

Journalism is playing significant in order to create peace and harmony in diversity society. I have an experience in joining in journalism of diversity activity. Journalism of diversity comprises students from different religions background from various universities in Indonesia. This program is run every year with different attendances. Students are asked to have journalistic training for two weeks.

One of the programs of journalistic of diversity training was to visit a place of prayer of other's religion dialogue with the people in its places. I had a chance to visit Ashram which was a place where Hindus people learn their religion from their Guru. At the time I also attended their worship and meditation.

Dialogue of religious experience occurs when people steep in their spiritual traditions share their ways of searching for God or the Absolute. I have been practicing this dialogue as I have many family members who are Muslims. Many times, I have been invited to go to their mosque and attend their feast celebration. Moreover, I several times attended prayer for peace that is led by some people from different religions.

Dialogue of theological exchange happens when specialists seek to deepen their understanding of other spiritual heritages. I also have an experience of this form dialogue during my study in Indonesia. I sometimes attended some seminars or discussions about other religions. Moreover, several times our missiology lecturer invited Muslim imam and Hindu guru to a give lecture about their religions.

\section{Interreligious and Pancasila}

The understanding of the foundation of interreligious dialogue and my own experience of dialogue in four forms, lead me to look at the out coming of dialogue based on pancasila particularly according to it pillars. The first pillar is belief in one God. This pillar does not refer to theological concept or doctrine of any particular religion in Indonesia. Nevertheless, this pillar refers to an acknowledgment of the Supreme Being in every religion and traditional believe. It means that Indonesians are asked to respect all divine values of all religions and traditional believe. This concept is in same line with what Edward Schillebeeckx said that all word religions in principle are legitimatised as unique and particular revelation from the same God. Moreover, they also share something in common which is 'common experience' in their group about God.v

Accordingly, interreligious dialogue is a process to deepen my faith and understanding about God through an encounter with other from different religions background. Moreover, I also witness my faith to other without denying the beauty and the truth that they have. Therefore, based on the first pillar of pancasila and through the experience interreligious dialogue, I and all Christians are called to evangelise Christian faith and at the same time being evangelised by others in order to deepen our faith.vi

Second pillar is humanity. Humanity is the core of every religions and traditional believe. Through faith, believers are called to express this human fraternity by safeguarding creation and the entire universe and supporting all persons, especially the poorest and those most in need.vii

All religions are concerned with humanity, although they may have different practices or beliefs, they are mutually concerned with building a better world. Consequently, every form of interreligious should refer to humanity. Peace and harmony which create a better world are the most significant purpose of interreligious dialogue. Therefore, second pillar of pancasila becomes an inspiration for all Indonesians in doing interreligious dialogue in order to care for humanity.

Third pillar is democracy. Democracy is also a part of interreligious dialogue. In my experience of dialogue, I also joined the long march with some students in order to look for justice. It was an expression of democracy. There three mains out come of interreligious dialogue regarding democracy: first, promote human right values and law. Second, foster mutual respect, awareness, tolerance and mutual understanding. Lastly, seek an open and a transparent dialogue to practice virtues of civic and civil dialogue. viii Based these main out comes; the practise of interreligious dialogue in Indonesia's context is a way to fulfil this third pillar of pancasila.

Fourth pillar is the unity of Indonesia. Unity is the main purpose of interreligious dialogue. According to my experience of being involved in some forms dialogue, the first thing that I experienced and I felt was the sense of unity. Once I encounter with people in dialogue, I become part of them. In the same line, Raymond Panikkar argued that there are two attitudes in interreligious dialogue such as we meet as sister-religions striving towards the same goal which is the unity with others and we meet by sacrificing our differences so as to be united in the mystery of the divine.ix

Explicitly, unity is a goal of interreligious dialogue and it only occurs when everyone who involve in dialogue has to sacrifice their differences in order to welcome others. The pillar about unity is not merely refers to human dimension but it relates to transcendental where they become one in the mystery of the divine as they acknowledge in the first pillar. In Christian perspective, unity is the mystery of the dialogue. Augustine argued that love is the bond of unity and difference among the persons of the Trinity.x Therefore, dialogue in the spirit of love is to unite human beings as they picture the unity of the Trinitarian as their model.

The fifth pillar is social justice. Social justice is a universal language that used in interreligious dialogue. According to my experience, everyone from any religions usually has something in common which is the concern of social justice issue. In this case, the fifth pillar of pancasila becomes the basic of interreligious dialogue.

In Christian perspective, social justice is not merely as a basic of dialogue but it also leads to a proclamation through dialogue. The action justice is a way for all Christians to preach the gospel and proclaim Jesus Christ. This was stated by synod of bishops in 1971: 
Action on behalf of justice and participation in the transformation of the world fully appear to us as a constitutive dimension of the preaching of the Gospel, or, in other words, of the Church's mission for the redemption of the human race and its liberation from every oppressive situation. ${ }^{\mathrm{xi}}$

Through interreligious dialogue all Christian particularly Indonesians, even as a minority group that sometimes being persecuted are called to involve actively in social justice issue. It is not only to fulfil the fifth pillar of pancasila but it also goes beyond which is the proclamation of the Gospel through the action of justice. However, these out comes cannot be reached unless some challenges of interreligious dialogue are not allowed to live in Indonesia.

\section{The Challenges of Interreligious in Indonesia}

Pancasila has been becoming ideology of the country since Indonesia proclaimed its independence in 1945. However, there is still challenging in doing interreligious dialogue until today. Indonesia is still struggling with the majority and minority issues. When it relates to religious matters, many times the state tends to be on side with the majority and discriminates the minorities as well as letting some intolerant treatment towards the minorities take place.xii Moreover, religion is sometimes used by politicians in order to gain power during election. In this case, they manipulate people by confronting minority and majority religions. This reality blocks people to build up interreligious dialogue but also create tension and hatred between religions.

Other challenge of interreligious dialogue is fundamentalism and extremism. In Indonesia there are some fundamentalist group threaten other people from different religions and culture background for example, The Islamic Defenders Front and Jamaah Islamiah. The members of these two groups try to persecute and threaten others. Surely, fundamentalist is in every religion. Therefore, it is a necessary for every religion to eliminate fundamentalism.

\section{Conclusion}

To sum up, interreligious dialogue is an imperative for everyone who lives in a diverse society like Indonesia in order to live together harmonically and peacefully. The pancasila have to be applied in daily life through dialogue. The challenge is not an obstacle to quit, rather it nourishes the dialogue.

\section{References}

i. Ali, Mukti. (1992). Ilmu Perbandingan Agama: Dialog dan Misi Dakwah. In Belanda Burhanuddin Daya and Herman Leonard Beck (Ed.), Ilmu Perbandingan Agama di Indonesia. (pp. 226-230). Jakarta: INIS.

ii. Arthur, James. (2011). Intercultural versus Interreligious Dialogue in a Pluralist Europe. Policy Futures in Education, 9 (1),1-7.

iii. $\quad$ Daya, Burhanuddin. 2004. Agama Dialogis: Merenda Dialektika Idealita dan Realita

iv. Hubungan Antaragama. Yogyakarta: Mataram Minang Lintas Budaya.

v. De Margerie, Bertrand. (1982). The Christian Trinity in History. Petersham, Massachusetts: St. Bede's Publications.

vi. Francis and the Grand Imam, (2019). Human Fraternity: For World Peace and Living Together.

vii. https://press.vatican.va/content/salastampa/en/bollettino/pubblico/2019/02/04/190204f.html (accessed 10 April 2020).

viii. Jan Van, Wiele. (2012). The Universality and Particularity in Christianity in Edward Schillebeeckx's Theology of Religion. Studies in Interreligious Dialogue, 22 (1) 5-16.

ix. Jonathan, Andreas, Paulus Widjaja, and Fatimah Husein. (2016). Fostering Religious Exclusivism and Political Pluralism in Indonesia Through Interfaith-based Student Community. South East Asia Studies, 1-18.

x. Kasimow, Harold. (1999). John Paul II and Interreligious Dialogue. In Bryon L. Sherwin and Harold Kasimow. John Paul II and Interreligious Dialogue. Maryknoll, New York: Orbis Books.

xi. Mong, Ambrose. (2015). Plunging into Gangas-Raimundo Panikkar in Inter-Religious Dialogue. Asia Journal of Theology, 1, 1-21.

xii. Nazmudin, (2017). Kerukunan dan Toleransi Antar Umat Beragama dalam Membangun Keutuhan Negara Kesatuan Republik Indonesia (NKRI). Journal of Government and Civil Society, 1 (1), 23-39.

xiii. $\quad$ Pontifical Council for Inter-Religious Dialogue. (2019). Dialogue and Proclamation: Reflection and Orientations on Interreligious Dialogue and the Proclamation of the Gospel Jesus Christ.

http://www.vatican.va/roman_curia/pontifical_councils/interelg/index.htm. (accessed May 2020).

\footnotetext{
${ }^{i}$ Nazmudin, 'Kerukunan dan Toleransi Antar Umat Beragama dalam Membangun Keutuhan Negara Kesatuan Republik Indonesia (NKRI), Journal of Government and Civil Society 1, no. 1 (April 2017): 23-39.

ii Burhanuddin Daya, Agama Dialogis: Merenda Dialektika Idealita dan Realita Hubungan Antaragama (Yogyakarta: Mataram Minang Lintas Budaya, 2004), 1.

iii Mukti Ali, 'Ilmu Perbandingan Agama: Dialog dan Misi Dakwah' dalam Ilmu Perbandingan Agama di Indonesia, ed., Belanda Burhanuddin Daya dan Herman Leonard Beck (Jakarta: INIS, 1992): 226-230.

iv Pontifical Council for Inter-Religious Dialogue, Dialogue and Proclamation: Reflection and Orientations on Interreligious Dialogue and the Proclamation of the Gospel Jesus Christ

(28 May 2019), \#42.

http://www.vatican.va/roman_curia/pontifical_councils/interelg/documents/rc_pc_interelg_doc_19051991_dialogue-and-proclamatio_en.html. (Accessed 10 April 2020).

v Wiele Jan Van, 'The Universality and Particularity in Christianity in Edward Schillebeeckx's Theology of Religion,' Studies in Interreligious Dialogue 22, no. 1 (2012): 5-16.
} 
vi Harold Kasimow, 'John Paul II and Interreligious Dialogue,' In John Paul II and Interreligious Dialogue, ed., Bryon L. Sherwin and Harold Kasimow (Maryknoll, NY: Orbis Books, 1999), 40.

vii Pope Francis and the Grand Imam, Human Fraternity: For World Peace and Living Together (Abu Daby: 4 February 2019), https://press.vatican.va/content/salastampa/en/bollettino/pubblico/2019/02/04/190204f.html (accessed 10 April 2020).

viiiJames Arthur, 'Intercultural versus Interreligious Dialogue in a Pluralist Europe,' Policy Futures in Education 9, no.1 (2011):1-7.

ix Ambrose Mong, 'Plunging into Gangas-Raymond Panikkar in Inter-Religious Dialogue,' Asia Journal of Theology, 1 (October, 2015$)$ : 1-21.

x Bertrand de Margerie, The Christian Trinity in History (Petersham, Massachusetts: St. Bede's Publications, 1982), 110-121.

xi The Synod of Bishops, Second General Assembly (30 November 1971) 'Justice in the World', in The Gospel of Peace and Justice: Catholic Social Teaching since Pope John Paul II, ed., Joseph Gremillion, (Maryknoll, New York: Orbis Books, 1976), \#6.

xiiAndreas Jonathan, Paulus Widjaja, and Fatimah Husein, 'Fostering Religious Exclusivism and Political Pluralism in Indonesia Through Interfaith-based Student Community,' South East Asia Studies, (2016): 1-18. 